\footnotetext{
${ }^{1}$ Department of Genetics and Animal Breeding, August Cieszkowski Agricultural University of Poznan, Poland ${ }^{2}$ Equine Clinic, Department of Veterinary Clinical Studies, Vetsuisse Faculty, University of Berne, Switzerland ${ }^{3}$ Clinical Laboratory of the Vetsuisse-Faculty Zurich, University of Zurich, Switzerland

${ }^{4}$ Institute of Genetics, Vetsuisse Faculty, University of Berne, Switzerland
}

\title{
Cytogenetic mapping and STR polymorphism of two candidate genes (DRD2 and HTR1D) for behaviour traits in four canids
} (short communication)

\begin{abstract}
The dopamine D2 receptor (DRD2) and serotonin receptors 1D (HTR1D) are candidate genes for behavioural traits. In the present study, we show chromosomal location and polymorphism of these genes in four species from the family Canidae: dog (CFA), red fox (VVU), arctic fox (ALA) and the Chinese raccoon dog (NPP). Using fluorescence in situ hybridisation (FISH) the DRD2 gene was localized in the following chromosomes: CFA5q12-13, VVU12q21, ALA10q14 and NPP3q14 and the HTR1D gene was mapped to: CFA2q25, VVU2q22, ALA8q25 and NPP10q25. A microsatellite marker (TG) $)_{\mathrm{n}}$ in intron 3 of the DRD2 gene and (CA) motif located in a 3'-flanking region of the HTR1D gene were polymorphic in all studied species. The obtained results can be helpful in further studies on effects of polymorphisms of these genes on behaviour traits in canids.
\end{abstract}

Key Words: behaviour, Canidae, DRD2, HTR1D, gene mapping, microsatellite polymorphism

\section{Zusammenfassung}

Titel der Arbeit: Zwei Kandidaten-Gene (DRD2 und HTR1D) für Verhaltenseigenschaften: Cytogenetische Lokalisation und STR Polymorphismen in vier Canidae (Kurzmitteilung)

Der Dopamin D2 Rezeptor (DRD2) und die Serotonin Rezeptoren 1D (HTR1D) sind Kandidaten-Gene für Verhaltenseigenschaften. In der vorliegenden Studie werden die chromosomale Lokalisation und Polymorphismen dieser Gene in vier Arten der Familie Canidae: Hund (CFA), Rotfuchs (VVU), Polarfuchs (ALA) und Chinesischer Marderhund (NPP), gezeigt. Mit Hilfe der Fluoreszenz in situ Hybridisierung (FISH) konnte die Lokalisation des DRD2-Gens auf den folgenden Chromosomen identifiziert werden: CFA5q12-13, VVU12q21, ALA10q14 und NPP3q14. Das HTR1D-Gen wurde auf CFA2q25, VVU2q22, ALA8q25 und NPP10q25 lokalisiert. Ein Mikrosatellitenmarker (TG) ${ }_{\mathrm{n}}$ im Intron 3 des DRD2-Gens und ein (CA) $)_{\mathrm{n}}$ Motif, welches in der 3 `-Re- $^{-}$ gion des HTR1D-Gens lokalisiert ist, sind in allen Arten polymorph. Die erzielten Ergebnisse können in weiteren Studien, die sich über die Effekte von Polymorphismen dieser Gene auf das Verhalten in Canidae befassen, hilfreich sein.

Schlüsselwörter: Verhalten, Canidae, DRD2, HTR1D, Kartierung von Genen, Mikrosatelliten-Polymorphismen

\section{Introduction}

The family Canidae is consisted of 36 species, including dog (Canis familiaris) and three fur-bearing animals: red fox (Vulpes vulpes), arctic fox (Alopex lagopus) and Chinese raccoon dog (Nyctereutes procyonoides procyonoides). Due to extensive variability of behaviour traits observed in different dog breeds, the dog and silver fox are considered as a useful models to study genetic background of it (OSTRANDER and WAYNE, 2005; SPADY and OSTRANDER, 2007). 
Among candidate genes for behaviour traits there are dopamine D2 receptor (DRD2) and serotonin receptors 1D (HTR1D) genes. The DRD2 is one of five dopamine receptors and the encoded protein inhibits adenylyl cyclase activity and mitogenesis. It has been shown that mutation of this gene can be associated with human schizophrenia (GLATT et al., 2003). The serotonin is a neurotransmitter and genes encoding its receptors were mentioned to be associated with human mental disorders (BERGEN et al., 2003).

In this report we show chromosomal FISH-localization and STR polymorphism of DRD2 and HTR1D genes in four species of the family Canidae: dog (CFA), red fox (VVU), arctic fox (ALA) and Chinese raccoon dog (NPP).

\section{Materials and Methods}

Fragments of two genes (DRD2 and HTR1D) were amplified by PCR using a Tgradient thermocycler (Biometra, Goettingen, Germany). Primers for the $D R D 2$ gene used in this study were previously described by MYEONG et al. (2000). The genome sequence of this gene is also deposited in GenBank (AF_293962). The primers for HTR1D were as follows: F:5'ACTACGTATGTCTGGCAAAACTTC3' and R:5'TCTACACTCTCCCTTAAACACTGG3' (GenBank NW_876292). Amplifications were carried out in $20 \mu$ l containing $100 \mathrm{ng}$ of DNA, 15 pmol of each primer, $200 \mu \mathrm{M}$ of dNTP, $1 \times$ PCR buffer with $1.5 \mathrm{mM} \mathrm{MgCl}_{2}$ and 0.6 units Taq polymerase (Novazym, Poznan, Poland). The following PCR reaction conditions were applied: the initial denaturation at $94^{\circ} \mathrm{C}$ for 5 minutes, 35 cycles of denaturation at $94^{\circ} \mathrm{C}$ for 40 seconds, annealing of primers at $63^{\circ} \mathrm{C}$ for $D R D 2$ gene and $52^{\circ} \mathrm{C}$ for $H T R 1 D$ gene for 40 seconds, elongation at $72^{\circ} \mathrm{C}$ for 45 seconds, final elongation at $72^{\circ} \mathrm{C}$ for 10 minutes. One primer of each pair was labeled with Cy5 and DNA fragments were separated and detected on $8 \%$ denaturing polyacrylamide gel using automatic sequencer ALFexpressII (Amersham Bioscience, Buckinghamsire, UK). To confirm the presence of repetitive motifs in analysed fragmets of both genes, the samples of PCR products from one animal were sequenced at Institute of Biochemistry and Biophysics Polish Academy of Sciences, Warsaw, Poland.

Chromosome preparations were obtained from short-term lymphocyte cultures and stained by Q-banding technique prior to FISH. Chromosome nomenclatures for the dog (SWITONSKI et al., 1996), red fox (MÄKINEN et al., 1985a), arctic fox (MÄKINEN et al., 1985b) and the Chinese raccoon dog (PIENKOWSKA et al., 2002) were applied.

A canine genomic bacterial artificial chromosome (BAC) library (SCHELLING et al., 2002) was screened for DRD2 and HTR1D genes by PCR. DNA of the two BAC clones, containing sequences of the selected genes (S091P05C10 - for DRD2, S002P01E05 for HTR1D) was isolated and labeled with biotin 16-d-UTP by random priming. Fluorescence in situ hybridization was carried out as described earlier (SZCZERBAL et al., 2003). Slides were analyzed under a fluorescence microscope (Nikon E 600 Eclipse) equipped with a cooled digital CCD camera, driven by computer aided software Lucia.

Results

The selected BAC probes gave positive FISH signals in all studied species (Fig.). The $\mathrm{DRD} 2$ gene was localized in the following chromosomes: CFA5q12-13, VVU12q21, 
ALA10q14 and NPP3q14 and the HTR1D gene was assigned to: CFA2q11, VVU2q22, ALA8q25 and NPP10q25.

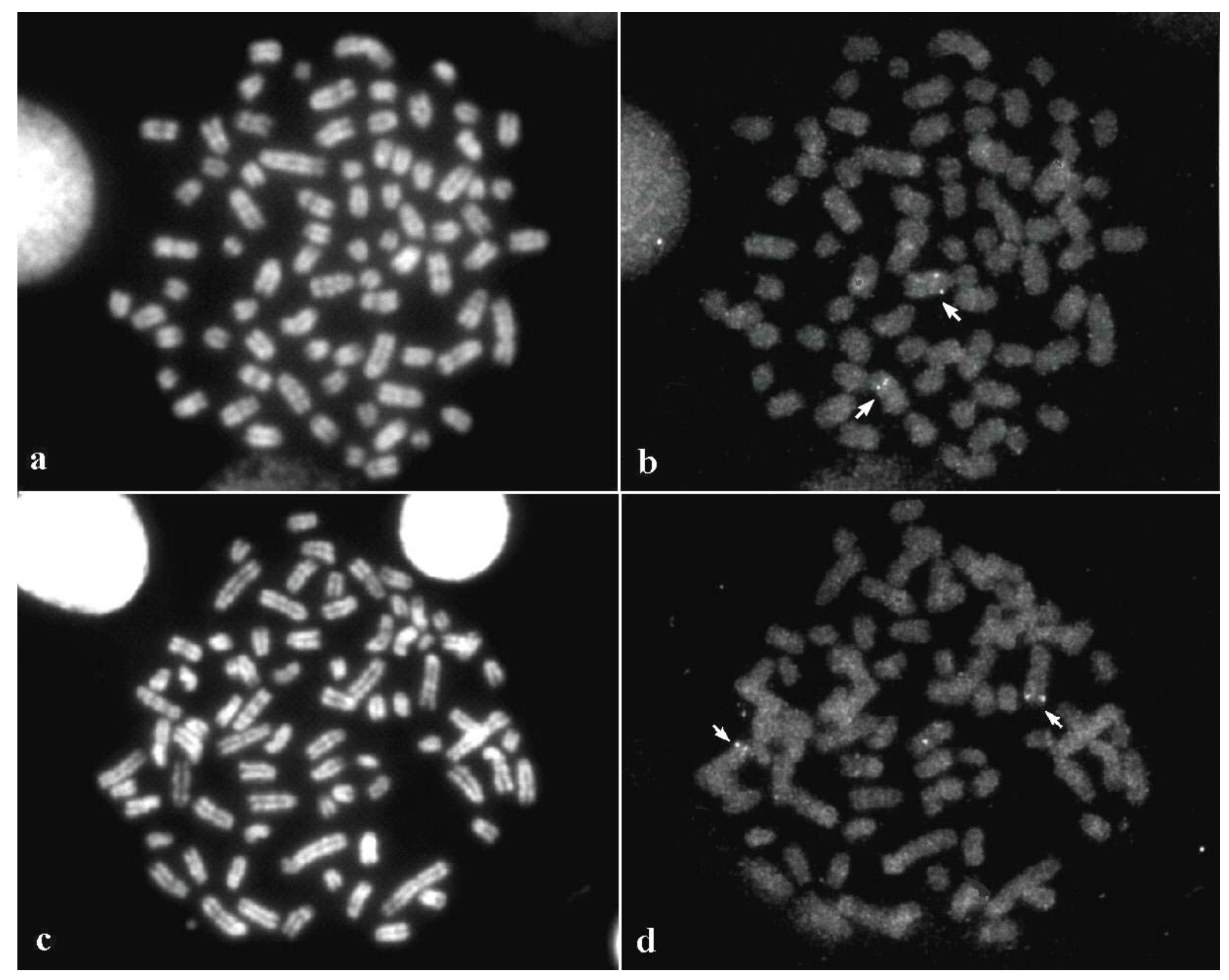

Fig.: The dog, Q-banded metaphase spreads (a, c) and the same spreads after FISH with the BAC probes harbouring DRD2 (b) and HTR1D genes (d) Hybridization signals are indicated by arrows (Der Hund, Q-Banden von Metaphasechromosomen (a, c) und FISH auf denselben Metaphasechromosem mit BAC Sonden der DRD2 (b) und HTR1D-Gene (d). Hybridisierungssignale sind durch Pfeile gekennzeichnet)

Obtained results are in agreement with data from comparative chromosome painting studies performed for canid species (GRAPHODATSKY et al., 2001; NIE et al., 2003). Moreover, in case of the $D R D 2$ gene our results confirm previous data obtained by radiation mapping for the dog (JEOUNG et al., 2000).

Within both genes polymorphism of the STR (microsatellite) markers was also studied. In the DRD2 gene a polymorphic sequence (TG) in the intron 3, described earlier in the dog (MYEONG et al., 2000), was analysed. In case of the HTR1D gene in silico analysis revealed a potentially polymorphic STR - $(\mathrm{CA})_{\mathrm{n}}$ - in the 3'flanking region.

Polymorphism was studied in DNA samples originated from 36 dogs, representing 18 breeds, and 70 fur animals kept on a farm (24 Chinese raccoon dogs, 24 red foxes and 22 arctic foxes). Sequencing of PCR products confirmed the presence of (TG) $)_{11}$ repeated motif in intron 3 of the $D R D 2$ gene and $(C A)_{23}$ motif in 3'flanking region of the HTR1D gene. Number of alleles, size range, heterozygosity (HET) and polymorphism information content (PIC) values are shown in the Table. The analyzed 
STR markers appeared to be highly polymorphic and thus will be useful in the association studies.

Table

Chromosome location and polymorphism of DRD2 and HTR1D genes in dog, red fox, arctic fox and Chinese raccoon dog (Chomosomenlokalisation und Polymorphismen der DRD2 und HTR1D-Gene bei Hund, Rotfuchs, Polarfuchs und Chinesischem Marderhund)

\begin{tabular}{|c|c|c|c|c|c|}
\hline & Gene & Dog & Red fox & Arctic fox & $\begin{array}{c}\text { Chinese raccoon } \\
\text { dog }\end{array}$ \\
\hline \multirow[t]{5}{*}{ DRD2 } & $\begin{array}{l}\text { Chromosome } \\
\text { location }\end{array}$ & $5 q 12-13$ & 12q21 & 10q14 & $3 q 14$ \\
\hline & $\begin{array}{l}\text { Number of } \\
\text { allels }\end{array}$ & 5 & 5 & 4 & 2 \\
\hline & Size range $^{\text {a) }}$ & $11-17$ & $12-16$ & $10-15$ & $10-11$ \\
\hline & HET & 0.676 & 0.699 & 0.678 & 0.191 \\
\hline & PIC & 0.612 & 0.630 & 0.599 & 0.169 \\
\hline \multirow[t]{5}{*}{ HTR1D } & $\begin{array}{l}\text { Chromosome } \\
\text { location }\end{array}$ & $2 q 25$ & $2 q 22$ & $8 q 25$ & $10 q 25$ \\
\hline & $\begin{array}{l}\text { Number of } \\
\text { allels }\end{array}$ & 12 & 11 & 8 & 5 \\
\hline & Size range $^{\text {b) }}$ & $18-29$ & $6-21$ & $10-19$ & $16-22$ \\
\hline & HET & 0.872 & 0.869 & 0.730 & 0.480 \\
\hline & PIC & 0.845 & 0.835 & 0.679 & 0.440 \\
\hline
\end{tabular}

a) - number of repeated motif (TG) in intron 3; b) - number of repeated motif (CA) in 3'flanking region

\section{Discussion}

To understand genetic background of behaviour traits several other candidate genes were recently analyzed. The dopamine receptor D4 (DRD4) gene polymorphism was studied in 23 dog breeds, including 1535 unrelated individuals (ITO et al., 2004). The authors divided the studied dogs into two groups, taking into consideration behaviour traits, and found that some alleles were more frequent in the group with a higher average score of "aggressiveness" and the others in a group with the lower score. Also other genes (HTR1A, HTR2A, HTR1B, and HTR2C), encoding canine serotonin receptors, were considered (KLUKOWSKA-ROTZLER et al., 2005; MASUDA et al., 2004; VAN DEN BERG et al., 2005). In the HTR1A gene microsatellite markers (KLUKOWSKA-ROTZLER et al., 2005) and two nonsynonymous SNPs were found (VAN DEN BERG et al., 2005). Interbreed allele and genotype frequency differences in case of four SNPs, found in HTR1B gene, were identified (MASUDA et al., 2004).

To our knowledge this study brings new data on chromosome gene localisation and microsatellite polymorphism of two genes (DRD2 and HTR1D) which were not yet been studied in the fur-bearing species. This may enable further studies on verification of the major role of these candidate genes.

Recently, a linkage mapping of 320 microsatellite markers in the silver fox, performed on thirty-four pedigrees, originating from breeding tame and aggressive strains, were published (KUKEKOVA et al., 2007). Genome scanning of such reference families, will probably result in identification of chromosomal regions harbouring genes for behaviour. 


\section{Acknowledgements}

J. Nowacka-Woszuk is a holder of the Young Scientists' Fellowship (Foundation for Polish Science, contract 72/2006).

\section{References}

BERGEN, A.W.; VAN DEN BREE, M.B.; YEAGER, M.; WELCH, R.; GANJEI, J.K.; HAQUE, K.; BACANU, S.; BERRETTINI, W.H.; GRICE, D.E.; GOLDMAN, D.; BULIK, C.M.; KLUMP, K.; FICHTER, M.; HALMI, K.; KAPLAN, A.; STROBER, M.; TREASURE, J.; WOODSIDE, B.; KAYE, W.H.:

Candidate genes for anorexia nervosa in the 1p33-36 linkage region: serotonin 1D and delta opioid receptor loci exhibit significant association to anorexia nervosa. Mol. Psychiatry 8 (2003), 397-406

GLATT, S.J; FARAONE, S.V.; TSUANG, M.T.:

Meta-analysis identifies an association between the dopamine D2 receptor gene and schizophrenia. Mol. Psychiatry 8 (2003), 911-915

GRAPHODATSKY, A.S.; YANG, F.; O’BRIEN, P.C.M.; PERELMAN, P.; MILNE, B.S.; SERDUKOVA, N.; KAWADA, S.I.; FERGUSON-SMITH, M.A.:

Phylogenetic implications of the 38 putative ancestral chromosome segments for four canid species. Cytogenet. Cell Genet. 92 (2001), 243-247

ITO, H.; NARA, H.; INOUE-MURAYAMA, M.; SHIMADA, M.K.; KOSHIMURA, A.; UEDA, Y.; KITAGAWA, H.; TAKEUCHI, Y.; MORI, Y.; MURAYAMA, Y.; MORITA, M.; IWASZKI, T.; OTA, K.; TANABE, Y.; ITO, S.:

Allele frequency distribution of the canine dopamine receptor D4 gene exon III and I in 23 breeds. J. Vet. Med. Sci. 66 (2004), 815-820

JEOUNG, D.; MYEONG, H.; LEE, H.; HA, J.; GALIBERT, F.; HITTE, C.; PARK, C.:

A SINE element in the canine D2 dopamine receptor gene and its chromosomal location. Anim Genet. 31 (2000), 334-335

KLUKOWSKA-ROTZLER, J.; SZCZERBAL, I.; BRAUNSCHWEIG, M.; SWITONSKI, M.; SCHELLING, C.; DOLF, G.: Mapping and development of four microsatellite markers for the canine 5'-hydroxytryptamine serotonin receptor 2A (HTR2A). Anim Genet. 36 (2005), 173-175

KUKEKOVA, A.V.; TRUT, L.N.; OSKINA, I.N.; JOHNSON, J.L.; TEMNYKH, S.V.; KHARLAMOVA, A.V.; SHEPELEVA, D.V.; GULIEVICH, R.G.; SHIKHEVICH, S.G.; GRAPHODATSKY, A.S.; AGUIRRE, G.D.; ACLAND, G.M.:

A meiotic linkage map of the silver fox, aligned and compared to the canine genome. Genome Res. 17 (2007), 387-399

MÄKINEN, A.; KUOKKANEN, M.T.; ISAKOVA, G.K.; TAKAGI, N.; GUSTAVSSON, I.: The standard karyotype of the silver for (Vulpes fulvus Desm.). Hereditas 103 (1985a) 171-176

MÄKINEN, A.; GUSTAVSSON, I.; SWITONSKI, M.; TAKAGI, N.: The standard karyotype of the blue fox (Alopex lagopus L.). Hereditas 103 (1985b), 33-38

MASUDA, K.; HASHIZUME, C.; OGATA, N.; KIKUSUI, T.; TAKEUCHI, Y.; MORI, Y.: Sequencing of canine 5-hydroxytriptamine receptor (5-HTR) 1B, 2A, 2C genes and identification of polymorphisms in the 5-HTR1B gene. J. Vet. Med. Sci. 66 (2004), 965-972

MYEONG, H.; JEOUNG ,D.; KIM, H.; HA, J.H.; LEE, Y.; KIM, K.H.; PARK, C.; KAANG, B.K.: Genomic analysis and functional expression of canine dopamine D2 receptor. Gene 257 (2000), 99-107

NIE, W.; WANG, J.; PERELMAN, P.; GRAPHODATSKY, A.S.; YANG, F.: Comparative chromosome painting defines the karyotypic relationships among the domestic dog, Chinese raccoon dog and Japanese raccoon dog. Chromosome. Res. 11 (2003), 735-740

OSTRANDER, E.A.; WAYNE, R.K.: The canine genome. Genome Res. 15 (2005), 1706-1716

PIENKOWSKA, A.; SZCZERBAL, I.; MAKINEN, A.; SWITONSKI, M.: G/Q-banded chromosome nomenclature of the Chinese raccoon dog, Nyctereutes procyonoides procyonoides Gray. Hereditas 137 (2002), 75-78

SCHELLING, C.; SCHLAPFER, J.; BILLAULT, A.; GUZIEWICZ, K.; GMUR, A.; KATMANN, I.; PINEROLI, B.; COLOMB, B.; RICKLI, O.; WITTWER, C.; PIASECKA, A.; DOLF, G.: Construction of a canine Bacterial Artificial Chromosome library for screening with PCR. J. Anim. Breed. Genet. 119 (2002), 400-401

SPADY, T.C.; OSTRANDER, E.A.:

Canid genomics: mapping genes for behavior in the silver fox. Genome Res. 17 (2007), 259-263

SWITONSKI, M.; REIMANN, N.; BOSMA, A.A.; LONG, S.; BARTNITZKE, S.; PIENKOWSKA, A.; MORENO-MILAN, M.M.; FISCHER, P.: 
Report on the progress of standardization of the G-banded canine (Canis familiaris) karyotype. Chromosome. Res. 4 (1996), 306-309

SZCZERBAL, I.; ROGALSKA-NIZNIK, N.; KLUKOWSKA, J.; SCHELLING, C.; DOLF, G.; SWITONSKI, M.:

Comparative chromosomal localization of the canine-derived BAC clones containing LEP and IGF1 genes in four species of the family Canidae. Cytogenet. Gen. Res. 102 (2003), 264-266

VAN DEN BERG, L.; KWANT, L.; HESTAND, M.S.; VAN OOST, B.A.; LEEGWATER, P.A.:

Structure and variation of three canine genes involved in serotonin binding and transport: the serotonin receptor 1A gene (htr1A), serotonin receptor 2A gene (htr2A), and serotonin transporter gene (slc6A4). J. Hered. 96 (2005), 786-796

Received: 2006-10-20

Accepted: 2007-04-19

Authors' addresses

Dr. IZABELA SZCZERBAL, JOANNA NOWACKA-WOSZUK, MAGDALENA RACKA Prof. Dr. MAREK SWITONSKI*

Department of Genetics and Animal Breeding,

August Cieszkowski Agricultural University of Poznan,

Wolynska 33,60-637 POZNAN, POLAND

*Corresponding Author, E-mail: switonsk@jay.au.poznan.pl

E-mail: izabel@jay.au.poznan.pl

E-mail: jnowacka@jay.au.poznan.pl

Dr. JOLANTA KLUKOWSKA-ROETZLER, Equine Clinic, Department of Veterinary Clinical Studies, Vetsuisse Faculty, University of BERNE, SWITZERLAND

Dr. CLAUDE SCHELLING, Clinical Laboratory of the Vetsuisse-Faculty Zurich, University of ZURICH, SWITZERLAND

Dr. GAUDENZ DOLF, Institute of Genetics, Vetsuisse Faculty, University of BERNE, SWITZERLAND 